\title{
Human Pulmonary Endothelial Cells in Culture
}

\section{ACTIVITIES OF CELLS FROM ARTERIES AND CELLS FROM VEINS}

\author{
Alice R. Johnson, Department of Pharmacology, University of Texas Health \\ Science Center, Dallas, Texas 752.3.5
}

A B S T R A C T Endothelial cells were cultured from various different human vessels, including aortas, pulmonary, ovarian, and umbilical arteries, and pulmonary, ovarian, and umbilical veins. The cultured cells were identified as endothelial cells by the presence of Factor VIII antigen and antiotensin I converting enzyme (kininase II). They retained these markers for at least five passages in culture, and some cells had them for seven passages or more. Endothelial cells from the various vessels were compared with respect to their ability to metabolize angiotensins I and II and bradykinin. Cells from arteries had three to five times the angiotensin I converting enzyme activity as cells from veins. The activity of angiotensinase A (aspartyl aminopeptidase) had a similar distribution, and cells from arteries were consistently more active than cells from veins. Cultures of endothelial cells from pulmonary and umbilical vessels formed prostacyclin in response to mechanical stimulation. Media from cell monolayers that were subjected to a change of medium and gentle agitation inhibited aggregation of human platelets. This inhibitory activity was generated within $2-5 \mathrm{~min}$, and it was not formed by cells that were treated with indomethacin or tranylcypromine. Addition of prostaglandin (PG) $\mathrm{H}_{2}$ to indomethacin-treated cells restored the ability to form the inhibitor, but cells treated with tranylcypromine were not responsive to $\mathrm{PGH}_{2}$. In experiments where $\left[{ }^{14} \mathrm{C}\right.$ ]arachidonic acid was added to the cells before stimulation, the major metabolite identified by thin-layer chromatography was 6-keto PGF $_{1 \alpha}$. Thus, it appears that pulmonary endothelial cells, as well as umbilical cord cells, can form prostacyclin. In experiments comparing the ability of arterial and venous cells to form prostacyclin, arterial cells were more active than venous cells. These studies of cells from various human vessels suggest that the vascular origin of cultured endothelial cells determines how they metabolize vasoactive peptides and form prostacyclin.

Received for publication 9 May 1.979 and in revised form 7 November 197.9.

\section{INTRODUCTION}

The pulmonary vascular endothelium is a major site for the metabolism of bradykinin and angiotensin I. The angiotensin I converting enzyme (EC 3.4.15.1; kininase II; peptidyl dipeptidase) is localized on plasma membranes of endothelial cells $(1,2)$ where it can activate angiotensin I and inactivate bradykinin by cleavage of a carboxyl terminal dipeptide from these substrates $(3,4)$.

Angiotensin I is activated in other vascular beds as well (5-7), and angiotensin I converting enzyme has been identified by fluorescent antibodies in endothelium of aorta (8) and many different organs (2). Although angiotensin II is not inactivated during passage through the pulmonary circulation $(9,10)$, it is readily inactivated in other vascular beds (11).

The culture of endothelial cells has stimulated studies of their morphologic and functional properties. Endothelial cells have been cultured from veins of human umbilical cords (12-16), vena cavae of rabbits (17), and large arterial vessels of pigs (18-20) and cows (21-24). Most cultured endothelial cells retain the features of endothelium in vivo, including an epithelioid shape and Weibel-Palade bodies in the cytoplasm (25-27). Factor VIII antigen is associated with cells from human veins $(12,15)$ and with cells from aortas of animals (19, 21, 24). Angiotensin I converting enzyme activity is found in cells from umbilical cord veins $(15,16)$ and also in aortic endothelial cells from various species $(20,28,29)$. Cultured endothelial cells can transport serotonin (22) and adenine nucleotides (20), and they can form prostacyclin in response to mechanical or enzymatic stimulation (30-33).

The extensive surface provided by pulmonary capillary endothelium could account for the efficiency of the lung in metabolism of vasoactive peptides (11). Alternatively, the pulmonary vascular endothelium may have greater enzymatic activities than endothelium in other vascular beds. This study of endothelial cells cultured from different human vessels was made to determine whether the origin of the cell affects its ability to metabolize vasoactive peptides or to form prostacyclin. 
Some results were reported previously in abstracts $(16,34)$.

\section{METHODS}

Materials. Culture media, trypsin, collagenase, and antibiotics (penicillin, fungizone, and streptomycin) were purchased from Grand Island Biological Co. (Grand Island, N. Y.). Bradykinin and angiotensin II were purchased from Bachem Fine Chemicals Inc. (Marina del Rey, Calif.). Assay kits for angiotensin I converting enzyme were from Ventrex, Inc. (Portland, Maine). Antibodies to Factor VIII antigen and fluorescein isothiocynate (FITC)'-labeled goat anti-rabbit gamma globulin were purchased from Behring Diagnostics (Somerville, N. J.). Tranylcypromine was obtained from SmithKline Diagnostics Div., SmithKline Corp., Sunnyvale, Calif. Indomethacin, sodium arachidonate, ADP, $\alpha$-L-aspartyl $\beta$-naphthylamide, and $\beta$-naphthylamine were from Sigma Chemical Co. (St. Louis, Mo.). Labeled $\left[1-^{14} \mathrm{C}\right]$ arachidonic acid $(40-60 \mathrm{mCi} / \mathrm{mmol})$ was from New England Nuclear (Boston, Mass.). Prostacyclin, prostaglandin ( $\mathrm{PG}) \mathrm{E}_{2}, \mathrm{PGF}_{2 \alpha}$, 6-keto $\mathrm{PGF}_{1 \alpha}$, and the stable endoperoxide, U-41669, were generously donated by Dr. J. E. Pike of the Upjohn Co. (Kalamazoo, Mich.). The endoperoxide, $\mathrm{PGH}_{2}$, was kindly provided by Dr. William Campbell of the University of Texas Health Science Center (Dallas, Tex.).

Cell cultures. Endothelial cells were cultured from human umbilical cord veins and arteries as described previously (15). Cells were collected from aortas, pulmonary and ovarian vessels by a modification of this technique (see below). Ovarian vessels were obtained from surgical specimens removed during ovariosalpingectomy. All tissues were from individuals between the age of 23 and 54 yr. Pulmonary vessels and aortas were obtained from cadavers within $2-4 \mathrm{~h}$ postmortem. This material was taken only from individuals without obvious vascular or pulmonary disease. The ages of the cadaver donors ranged from $20-45 \mathrm{yr}$.

Most vessels from surgical specimens or cadavers yielded viable cells, and in 55 separate cultures initiated, only 3 failed to grow. Bacterial contamination was responsible for loss of five others. Cultures from 15 different ovarian arteries, 5 ovarian veins, 18 pulmonary arteries, and 9 pulmonary veins were used in this study. Most cultures were examined for Factor VIII antigen and tested for enzyme activity between the first and third passage, but a few cultures were tested as late as the seventh passage.

Pulmonary arteries and veins were dissected from whole lungs down to the level of the third and fourth branching points. Ovarian vessels were dissected from the ovarian ligament, and all vessels were cleaned free of adhering connective tissues, rinsed in protein-free culture medium, and placed on moist, sterile gauze in a small petri dish. While trypsin $(0.125 \%)$ was used for some preparations from umbilical (15) or pulmonary $(16,34)$ vessels, most of the cultures in this study were started from cells detached with $0.25 \%$ collagenase. The enzyme was introduced into the vessel lumen with a polyethylene-tipped syringe, and the endothelial surfaces were gently rubbed together, but the branches and ends of the vessel were not clamped. The specimens were covered with moist gauze and placed in a $37^{\circ} \mathrm{C}$ incubator for $10-15 \mathrm{~min}$. The detached cells were collected by washing the endothelial surfaces with protein-free culture medium. The cells were rinsed into tubes containing $5 \mathrm{ml}$ of medium plus antibiotics and $30 \%$ fetal calf serum. They were centrifuged to a pellet,

${ }^{1}$ Abbreviations used in this paper: FITC, fluorescein isothiocynate; PG, prostaglandin. washed once, and resuspended in $2-4 \mathrm{ml}$ of medium that contained $20 \%$ fetal calf serum and $10 \%$ human serum (type $\mathrm{O}^{+}$). The cells were plated in $35 \times 10 \mathrm{~mm}$ culture dishes and were allowed to remain undisturbed in a $37^{\circ} \mathrm{C}$ incubator for $1-3 \mathrm{~h}$. After cell attachment was ascertained by examining the dishes with an inverted microscope, the media was removed, and the attached cells were covered with fresh medium. The medium on new cultures was changed daily for the first $3 \mathrm{~d}$ and then every $3 \mathrm{rd} \mathrm{d}$ after that.

Cultures of endothelial cells from pulmonary, ovarian, or aortic vessels initiated from a small number of cells $\left(<10^{4}\right)$ obtained from enzyme treatment of the vessels. At least one passage was required before adequate material was obtained for enzyme assays, but Factor VIII antigen could be determined from plating a portion of the initial culture on coverslips. Umbilical vessels yielded a larger number of cells, but these cultures were usually transferred once before enzyme assay. The number of cells in each culture was determined by counting detached cells in a Coulter counter (Coulter Electronics Inc., Hialeah, Fla.) or by measurement of DNA (35). All cultures used for enzyme determinations were between 70 and $80 \%$ confluent, and all cultures, regardless of origin, were grown in the same media and subjected to the same schedule of media change.

Enzyme assays. Enzyme assays were made with disrupted cells. The cell monolayers were washed three times with protein-free culture medium $(10 \mathrm{ml})$ and the cells were scraped with a rubber spatula into $0.5-2 \mathrm{ml}$ of medium. The samples were sonicated for $10 \mathrm{~s}$ with a Branson probe sonifier (Branson Sonic Power, Danbury, Conn.). The material was centrifuged to a pellet, washed once, and the wash was pooled with the original supernatant medium. Initial determinations of enzyme activities in the supernate and cell fractions showed that more than $90 \%$ of the activity was in the supernatant medium.

The activity of angiotensin I converting enzyme was measured with two different substrates, bradykinin and $\left[{ }^{3} \mathrm{H}\right]-$ hippuryl glycylglycine. When bradykinin $(2 \mu \mathrm{M})$ was the substrate, inactivation of the peptide was measured by bioassay on the estrus rat uterus in vitro. Cell-free lysates were incubated with bradykinin in $0.2 \mathrm{M}$ Tris-maleate buffer $(\mathrm{pH} 7.4)$ with $0.2 \mathrm{M} \mathrm{NaCl}$ at $37^{\circ} \mathrm{C}$. Aliquots $(50 \mu \mathrm{l})$ of the reaction mixture were drawn immediately after and at $2.5 \mathrm{~min}$ intervals after addition of the substrate. These were diluted with $0.2-0.5 \mathrm{ml}$ of ice-cold saline and tested immediately on the rat uterus. The amount of kinin remaining in each aliquot was estimated by comparison with standard solutions of bradykinin. The specificity of inactivation by angiotensin I converting enzyme (kininase II) was established by incubating selected samples with $0.1 \mathrm{mM}$ SQ 20881 (36). All bioassays were performed in duplicate for a single cell culture. Enzyme activity was expressed as nanomoles of kinin inactivated per hour per $10^{6}$ cells.

When $\left[{ }^{3} \mathrm{H}\right]$ hippuryl glycylglycine was the substrate, $\left[{ }^{3} \mathrm{H}\right]-$ hippuric acid was extracted into ethyl acetate, and the radioactivity was measured in a liquid scintillation counter (37). The reaction was linear with time between 0 and $12 \mathrm{~h}$ at $37^{\circ} \mathrm{C}$. Triplicate samples were incubated both with and without $0.1 \mathrm{mM}$ SQ 20881 for $0-5 \mathrm{~h}$ after addition of the substrate. Activity was calculated from the difference in radioactivity in the organic phase between the 0- and 5-h samples and expressed as nanomoles of substrate hydrolyzed per hours per $10^{6}$ cells.

The activity of angiotensinase A was measured with both angiotensin II and $\alpha$-L-a spartyl $\beta$-naphthylamide as substrates. Angiotensin II $(14 \mu \mathrm{M})$ was added to cell samples in $0.2 \mathrm{M}$ Tris maleate buffer with $0.2 \mathrm{M} \mathrm{NaCl}(\mathrm{pH} 7.0)$. Aliquots for bioassay on the rat uterus were drawn immediately after addition of the 
substrate and at $2.5 \mathrm{~min}$ intervals thereafter. $o$-Phenanthroline $(1 \mathrm{mM})$ was added to inhibit the reaction in one set of samples (15).

Aspartyl-aminopeptidase activity was measured in cells incubated with $0.7 \mathrm{mM} \alpha$-L-a spartyl $\beta$-naphthylamide in $0.2 . \mathrm{M}$ Tris maleate buffer (pH 7.0) that contained $5 \mathrm{mM} \mathrm{CaCl}_{2}(38)$. When $o$-phenanthroline was used to inhibit the reaction, it was added $15 \mathrm{~min}$ before addition of the substrate. All samples were incubated at $37^{\circ} \mathrm{C}$ for 0,30 , and $60 \mathrm{~min}$, and the reaction was stopped by addition of alkaline EDTA ( $\mathrm{pH} 12.0$ ) to a final concentration of $5 \mathrm{mM}$. Fluorescence of the product, $\beta$-naphthylamine, was measured at $410 \mathrm{~nm}$ in an AmincoBowman spectrophotofluorometer (American Instrument Co., Travenol Laboratories Inc., Silver Spring, Md.), and the readings were compared with those of standard concentrations of $\beta$-naphthylamine.

Factor VIII antigen. Factor VIII antigen was identified in initial and passaged cultures of endothelial cells by an indirect fluorescent antibody technique $(12,39)$. Cultures were grown on glass coverslips from freshly isolated cells or from cells detached with trypsin at the time of transfer. They were fixed with $2.5 \%$ glutaraldehyde for $10 \mathrm{~min}$ at room temperature, rinsed with $1 \%$ sodium borhydride twice, with phosphatebuffered saline once, and rabbit anti-Factor VIII antigen in a dilution of 1:10 was applied to the surface of the coverslip in a volume of $250 \mu \mathrm{l}$. The coverslips were incubated at $37^{\circ} \mathrm{C}$ for $30 \mathrm{~min}$ in an atmosphere of $5 \% \mathrm{CO}_{2}$. They were washed well with three rinses of phosphate-buffered saline $(5 \mathrm{ml})$, and $250 \mu \mathrm{l}$ of a $1: 15$ dilution of FITC-labeled goat anti-rabbit gamma globulin was applied. After a second incubation of $30 \mathrm{~min}$ at $37^{\circ} \mathrm{C}$, the preparations were washed three times with phosphate-buffered saline and a final time with distilled water. They were mounted on slides with Permount (Fisher Scientific Co., Pittsburgh, Pa.) and examined with a Leitz orthoplan fluorescence microscope (E. Leitz, Inc., Rockleigh, N. J.). Controls were coverslips treated only with phosphate-buffered saline and FITC-labeled antiserum or coverslips treated first with normal rabbit serum and then with FITC-labeled antiserum.

Platelet aggregation. The inhibition of platelet aggregation by media from endothelial cell cultures was used as a bioassay for prostacyclin $(30,31)$. Venous blood was drawn from healthy volunteers who had not had any medication for $10 \mathrm{~d}$ previously. The blood was diluted with 0.1 volume of $3 \%$ trisodium citrate and centrifuged at $150 \mathrm{~g}$ for $10 \mathrm{~min}$. The platelet-rich plasma was removed and stored in a capped plastic tube at $25^{\circ} \mathrm{C}$. Platelet-poor plasma was prepared by further centrifugation at $600 \mathrm{~g}$ for $20 \mathrm{~min}$. The platelet suspensions were adjusted to $\sim 0.8 \times 10^{9}$ platelets $/ \mathrm{ml}$ with platelet-poor plasma. Aggregation was measured at $37^{\circ} \mathrm{C}$ in a Chrono-log aggregometer (Chrono-log Corp., Havertown, Pa.). Aggregating agents, ADP $(15-20 \mu . \mathrm{M})$, thrombin $(0.2-1 \mathrm{u} / \mathrm{ml})$, sodium arachidonate $(0.2-0.7 \mathrm{m.M})$, or $\mathrm{U}-41669(1 \mathrm{ng} / \mathrm{ml})$ were added in a volume of $10-50 \mu \mathrm{l}$ to $1 \mathrm{ml}$ of platelet suspension. Endothelial cell media tested for inhibition of aggregation were added in a volume of no more than $100 \mu \mathrm{l}$ $1 \mathrm{~min}$ before addition of an aggregating agent. Prostacrclin was prepared as a stock solution in $100 \%$ ethanol and diluted in phosphate-buffered saline just before use. Concentrations of $1-10 \mathrm{ng} / \mathrm{ml}$ of prostacyclin blocked all of the aggregating agents used.

Prostacyclin formation. Replicate cultures of endothelial cells were examined for prostacyclin formation after stimulation by a change of medium and agitation on a rocker platform. Monolayers of cells were treated with fresh culture medium (protein-free) that contained either tranylcypromine $(100 \mu \mathrm{g} / \mathrm{ml})$ or indomethacin $(1 \mu \mathrm{g} / \mathrm{ml})$. The flasks were placed on a rocker platform in the incubator and agitated gently for
2-30 min. Samples of media were taken immediately after the medium change and at 2, 5, 10, 15, and $30 \mathrm{~min}$. Sodium carbonate $(0.1 \mathrm{M})$ was added to each aliquot to bring the $\mathrm{pH}$ above 9 , and all samples were kept on ice until tested for inhibition of aggregation. For comparison of prostacyclin production by different cultures of cells, replicate monolavers were treated with fresh culture medium or with medium that contained tranylcypromine or indomethacin. After a brief incubation $(5 \mathrm{~min})$ this media was removed and $1 \mathrm{ml}$ of proteinfree culture medium was added to each flask. The cells were detached immediately by scraping with a rubber spatula and transferred to centrifuge tubes containing $0.1 \mathrm{M} \mathrm{Na} \mathrm{Na}_{2} \mathrm{CO}_{3}$. The cells were agitated with a vortex mixer, centrifuged to a pellet, and the supernatant medium was tested for inhibition of aggregation. In some experiments $\mathrm{PGH}_{2}(1 \mu \mathrm{g} / \mathrm{ml})$ was added immediately before scraping.

Thin-layer radiochromatography. The production of prostacyclin from arachidonic acid in cultured endothelial cells was established by the formation of 6-keto $\operatorname{PGF}_{1 \alpha}(30,32)$. This metabolite was identified after thin-laver chromotography of radiolabeled samples on silica gel thin-layer plates according to the method of Baenziger et al. (32). Monolavers of endothelial cells were washed with protein-free medium and treated with $5 \mu \mathrm{M}\left[{ }^{14} \mathrm{C}\right]$ arachidonic acid in medium adjusted to $\mathrm{pH} 8.6$. The cultures were incubated at $37^{\circ} \mathrm{C}$ for $30 \mathrm{~min}$ with the labeled precursor, then the medium was removed, the cells were scraped as described above, and centrifuged to a pellet. The supernatant medium was acidified to $\mathrm{pH} 4$ with glacial acetic acid and $50 \mu \mathrm{g}$ of $\mathrm{PGE}_{2}, \mathrm{PGF}_{2 \alpha}$, and 6-keto $\mathrm{PGF}_{1 \alpha}$ were added. The medium was extracted twice with 10 volumes of ethyl acetate, dried under $\mathrm{N}_{2}$, and the residue was dissolved in a small volume of chloroform: methanol $(2: 1)$. Each sample was spotted individually on a $5 \times 20-\mathrm{cm}$ silica gel plate and chromatographed in a solvent system of ethyl acetate:acetic acid:trimethylpentane (110:20:50). Standards of $\mathrm{PGE}_{2}, \mathrm{PGF}_{2 \alpha}$, and 6-keto $\mathrm{PGF}_{1 \alpha}$ were chromatographed on a separate plate. Separation of the prostaglandins was improved by drying each plate and running it a second time in the same solvent. At the end of the second chromatography, the standard plates were sprayed with $3.5 \%$ phosphomolybdic acid to develop the spots corresponding to the prostaglandins. The radiolabeled test plates were scanned in a Packard chromatograph scanner (Packard Instrument Co., Inc., Downers Grove, Ill.) and the radioactive peaks were compared with the spots developed on the standard plates.

\section{RESULTS}

Cell cultures. Endothelial cells from all of the vessels examined had a similar appearance under phase microscopy. All cultures started from small clumps of cells and spread into monolayers within $\sim 2-3 \mathrm{wk}$. Cells from adult vessels grew slowly at first and cells divided only at the edge of each clump. After 10-14 d in culture, however, cell division was more rapid, and transferred cells became confluent within a matter of days instead of weeks. Umbilical cord cells grew at a uniformly slow rate in both initial and transferred cultures. The appearance of endothelial cells from pulmonary artery is shown in Fig. 1.

Factor VIII antigen. Cells from all of the vessels examined had Factor VIII antigen as determined by combination with fluorescent antibody. No differences 

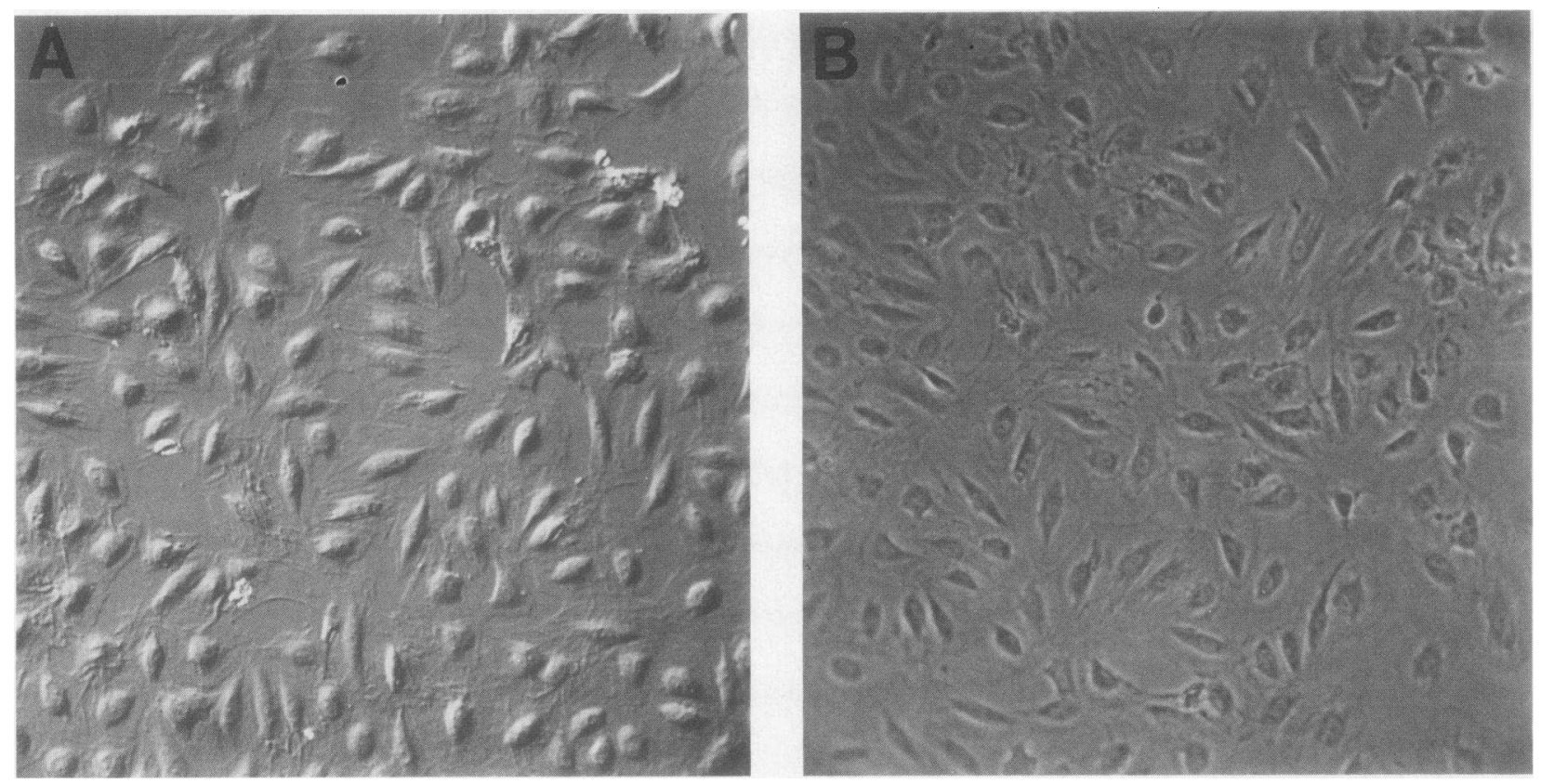

FIgURE 1 Pulmonary endothelial cells in culture. A shows a monolayer of cells viewed with Nomarski interference phase microscopy. B shows cells viewed with conventional phase microscopy. $\times 80$.

in the amount of material in cells from different vessels could be detected by this method. All of the cultures treated with antibody to Factor VIII and then with FITC-labeled anti-gamma globulin developed an intense yellow fluorescence. In contrast, cells treated with saline or with normal rabbit serum and FITC-antibody had only pale green background fluorescence. Fig. 2 shows the labeling of pulmonary and umbilical arterial cells with fluorescent antibody. Factor VIII antigen was present in all cultures examined between the first and fifth passages, and in four out of six cultures examined as late as the seventh passage. In two of the older cultures staining was diminished, and the cultures contained large, fibrillar cells that resembled smooth muscle cells. However, all cultures of pulmonary, umbilical, or ovarian cells that retained their epithelioid shape were positive for Factor VIII antigen.

Enzymatic activities. Angiotensin I converting enzyme (kininase II) activity was present in all cultures of endothelial cells studied. To establish that this marker was retained over the time of the enzymatic studies, three different cultures (one pulmonary vein and two pulmonary artery cultures) were tested at different passages. Fig. 3 shows the activity of the angiotensin I converting enzyme as measured by the hydrolysis of $\left[{ }^{3} \mathrm{H}\right]$ hippuryl glycylglycine. Although the activity was higher in the two arterial cultures than in the venous one, it remained constant for at least five passages. In one arterial culture a decrease in the enzymatic activity between the fifth and seventh pas- sages was associated with a change in the morphology of the cells. These cells became larger and assumed an overlapping, interwoven appearance similar to that of smooth muscle cells. This particular culture was also negative for Factor VIII antigen at the seventh passage.

The activity of angiotensin I converting enzyme in cells from arteries and veins was compared with two different substrates. Only cells in the first four passages were used for the enzyme determinations. With either bradykinin or $\left[{ }^{3} \mathrm{H}\right]$ hippuryl glycylglycine, the activity in cells from arteries was higher than in cells from veins. Fig. 4 shows the activity of angiotensin I converting enzyme measured by hydrolysis of $\left[{ }^{3} \mathrm{H}\right]-$ hippuryl glycylglycine in cells from aorta, pulmonary, ovarian, and umbilical vessels. Table I compares the inactivation of bradykinin by cells from four different pulmonary arteries and two different pulmonary veins. With either substrate the enzyme activity was inhibited more than $90 \%$ by SQ 20881 .

Angiotensinase activity was also higher in arterial cells than in venous cells. Table II shows the activity in pulmonary and umbilical arterial cells compared to the activity in umbilical vein cells. With either $\alpha$-Laspartyl $\beta$-naphthylamide or angiotensin II as a substrate, the arterial cells were four to five times more active than venous cells. The inhibition of the enzymatic activity by $o$-phenanthroline indicates that the enzyme is probably angiotensinase A (15).

Inhibition of platelet aggregation. Media from monolayers of endothelial cells collected after agitation 

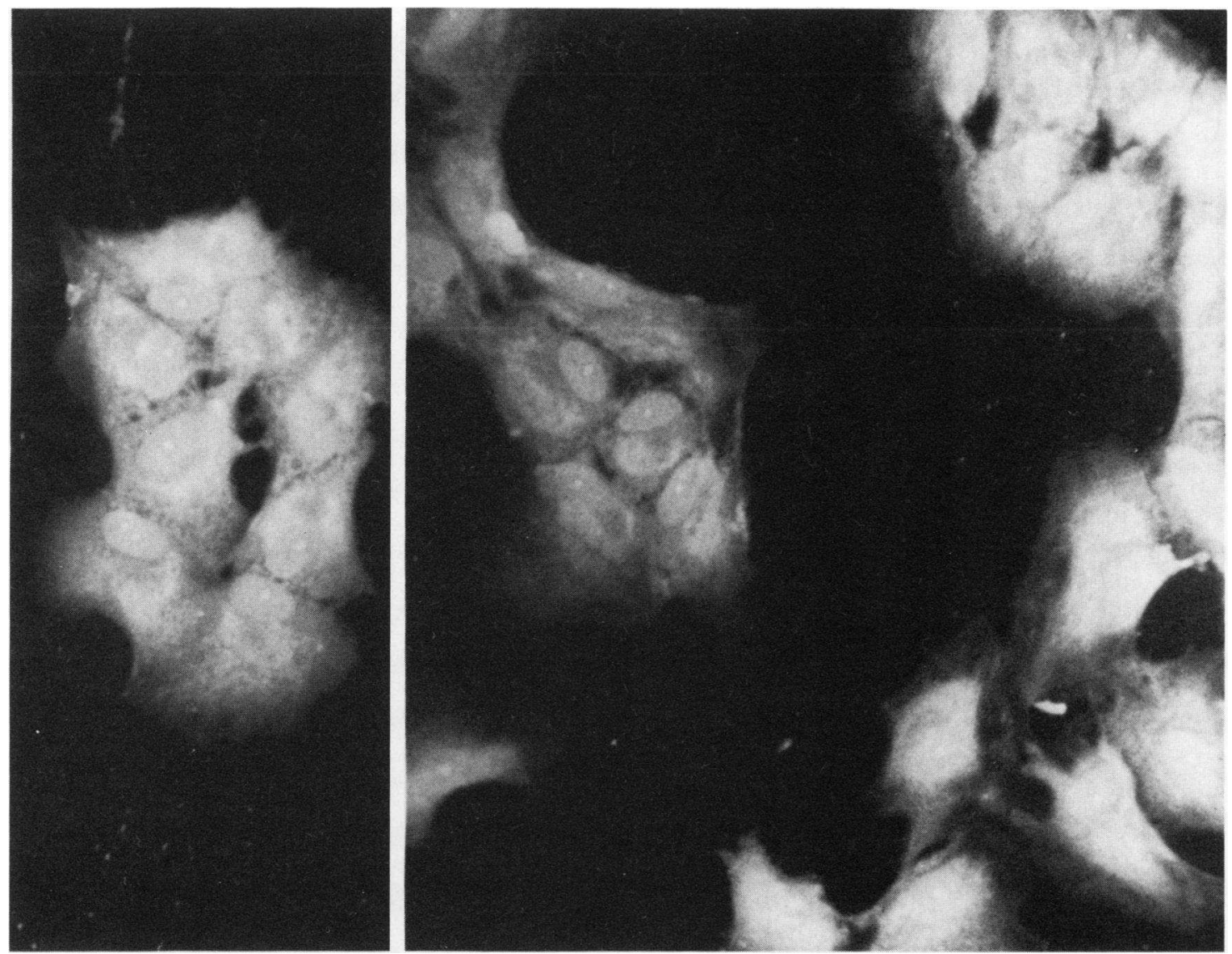

FIGURE 2 Factor VIII antigen in endothelial cells. The cells in the right panel are from umbilical artery, and those in the left are from pulmonary artery. Cells were treated first with rabbit antibody to Factor VIII antigen and then with FITC-labeled goat anti-rabbit gamma globulin. Both cultures were in the second passage.

on a rocker platform inhibited the aggregation of platelets caused by thrombin, ADP, sodium arachidonate, and the endoperoxide analog, U-41669. This inhibitory activity was generated within $2-5 \mathrm{~min}$ after the cells were stimulated by a change of medium and agitation, but it was not formed by cultures that were treated with either indomethacin or tranylcypromine (Fig. 5). The inhibitory activity formed by control (untreated) cultures was lost if the samples were acidified, or if they were heated to $100^{\circ} \mathrm{C}$ for $2 \mathrm{~min}$.

Scraping the cells with a rubber spatula provided a more vigorous stimulation for prostacyclin formation. Scraping and vigorous agitation on a vortex mixer increased the amount of prostacyclin to more than $\mathbf{5 0}$ times that formed by intact cell monolayers. The amount of prostacyclin formed by scraped cells increased still further if the endoperoxide, $\mathrm{PGH}_{2}$, was added just before scraping. Indomethacin and tranylcypromine blocked prostacyclin formation in scraped cells, but addition of $\mathrm{PGH}_{2}$ reversed the inhibition only in indomethacin-treated cells (Table III).
To compare prostacyclin formation by different cultures, duplicate flasks of cells were scraped and tested for inhibition of aggregation under standard conditions. The media were removed by suction, and $1 \mathrm{ml}$ of protein-free culture medium $(\mathrm{pH} 8.0)$ was added to each flask. The cells were scraped, centrifuged to a pellet and the supernatant medium was tested immediately in the platelet aggregation bioassay. An estimate of the amount of prostacyclin was made by comparison with standard solutions of prostacyclin. In three separate experiments pulmonary arterial cells formed more prostacyclin than either pulmonary or umbilical venous cells. These data are given in Table IV.

Thin-layer radiochromatography. To establish that the platelet-inhibitory activity from endothelial cells was prostacyclin, samples of media from scraped cells were chromatographed on silica gel plates and compared with several prostaglandin standards. The cell monolayers were treated first with labeled arachidonic acid and the labeled products identified by comigration 


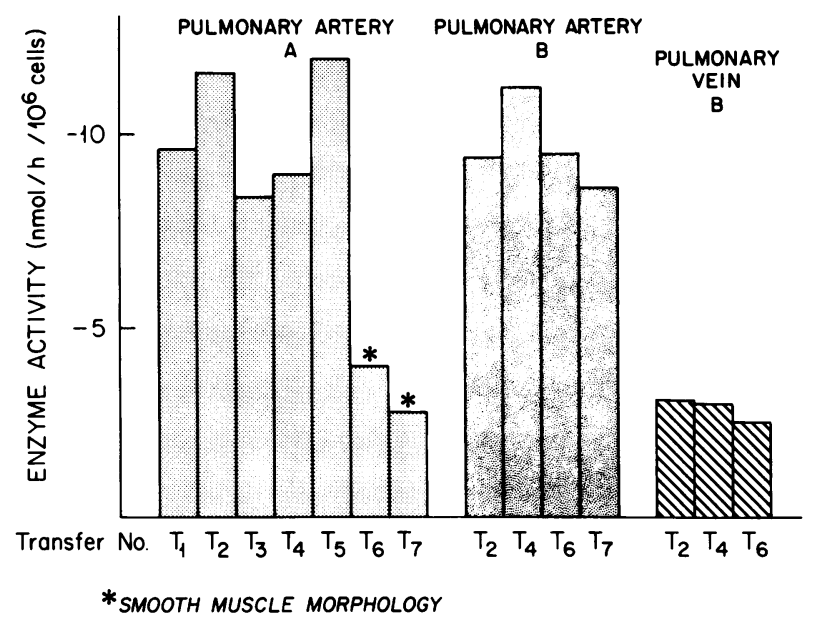

Figure 3 Angiotensin I converting enzyme in human pulmonary endothelial cells at different passages. Two cultures of pulmonary arterial cells and one of venous cells were examined after each passage. Enzyme activity, as measured by the hydrolysis of $\left[{ }^{3} \mathrm{H}\right]$ hippuryl glycylglycine, is indicated by the height of the bars. The number of each passage is on the abscissa.

with standard prostaglandins. Fig. 6 shows a scan of media from control cells and cells treated with indomethacin in juxtaposition to a thin-layer plate stained to show the migration of $\mathrm{PGE}_{2}, \mathrm{PGF}_{2 \alpha}$, and 6-keto $\mathrm{PGF}_{1 \alpha}$. In four experiments (two with pulmonary arterial cells and two with ovarian arterial cells) the major peak of radioactivity comigrated with 6-keto

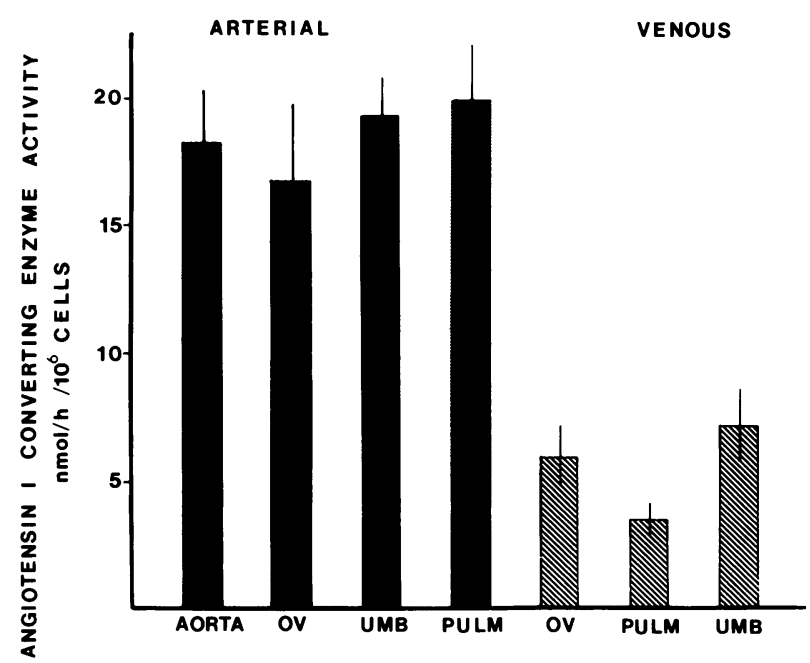

FIGURE 4 Activity of angiotensin I converting enzyme in cells cultured from different human vessels. Stippled bars indicate activity in arterial cells and hatched bars indicate activity in venous cells. All values are mean $\pm S E M$ of activities from 4 to 12 separate cultures. OV, ovarian cells; UMB, umbilical cord cells; and PULM, pulmonary cells. Enzyme activity was measured by hydrolysis of $\left[{ }^{3} \mathrm{H}\right]$ hippuryl glycylglycine.
TABLE I

Kininase Activity in Human Pulmonary Endothelial Cells

\begin{tabular}{ccc}
\hline Cell origin & Treatment & Enzyme activity \\
\hline \multirow{3}{*}{ Pulmonary artery } & None & nmol/h/10 cells \\
& SQ 20881 & $64.3 \pm 9.1$ \\
Plumonary vein & None & $3.2 \pm 0.1$ \\
& SQ 20881 & $14.4,20.6$ \\
& & $1.0,1.2$ \\
\hline
\end{tabular}

Inactivation of bradykinin $(2 \mu \mathrm{m})$ was measured on the rat uterus in vitro. Data for pulmonary arterial cells are mean $\pm S E M$ of four experiments and data for pulmonary vein cells are individual values from two separate experiments.

$\mathrm{PGF}_{1 \alpha}$. As shown in the figure, a small peak corresponding to $\mathrm{PGF}_{2 \alpha}$ followed the major peak. This product was eliminated by treating the cells with indomethacin before arachidonic acid stimulation, and the major 6-keto $\mathrm{PGF}_{1 \alpha}$ peak was greatly diminished.

\section{DISCUSSION}

Endothelial cells cultured from various human vessels have similar characteristics. They are epithelioid in shape, they contain Factor VIII antigen, angiotensin I converting enzyme, and angiotensinase $\mathrm{A}$, and they can form prostacyclin in response to mechanical stimulation.

Cells cultured from aorta, pulmonary, ovarian, or umbilical vessels retain angiotensin I converting enzyme and Factor VIII antigen for five or more passages. Because smooth muscle cells have neither converting enzyme activity (15) nor Factor VIII antigen $(12,40)$, the retention of these markers by the cultured cells used in this study indicates that they are endothelial cells. In one culture that was followed for multiple passages a decline in converting enzyme activity and Factor VIII antigen reactivity was associated with a change in morphology of the cells consistent with an overgrowth of smooth muscle cells. While a minor contamination with smooth muscle cells in the endothelial cultures cannot be excluded, the cells used in this study retained their endothelial characteristics throughout the time they were studied. Because smooth muscle cells exhibit a distinctive morphology $(14,24,26)$, a culture that was prominently contaminated could be easily identified.

Although the collection of the cells and the conditions of culture were the same for all of the cells studied, there was a striking difference in the enzymatic activities of cells derived from different vessels. Both angiotensin I converting enzyme and angiotensinase A were three to five times more active in cells from arteries than in cells from veins. This pattern persisted even though two different substrates were used 
TABLE II

Angiotensinase Activity in Endothelial Cells

\begin{tabular}{|c|c|c|c|}
\hline Cell origin & Substrate & Inhibitor & Enzyme activity \\
\hline & & & nmol/h/10 cells \\
\hline Umbilical vein & $\begin{array}{l}\alpha \text {-L-aspartyl } \beta \text {-naphthyl } \\
\quad \text { amide }\end{array}$ & $\begin{array}{l}\text { None } \\
o \text {-phenanthroline }\end{array}$ & $\begin{array}{l}0.5 \pm 0.0 \\
0.1 \pm 0.0\end{array}$ \\
\hline Umbilical artery & $\begin{array}{l}\alpha \text {-L-aspartyl } \beta \text {-naphthyl } \\
\text { amide }\end{array}$ & $\begin{array}{l}\text { None } \\
o \text {-phenanthroline }\end{array}$ & $\begin{array}{l}2.7 \pm 0.1 \\
0.7 \pm 0.0\end{array}$ \\
\hline Pulmonary artery & $\begin{array}{l}\alpha \text {-L-aspartyl } \beta \text {-naphthyl } \\
\text { amide }\end{array}$ & $\begin{array}{l}\text { None } \\
o \text {-phenanthroline }\end{array}$ & $\begin{array}{l}1.9 \pm 0.2 \\
0.3 \pm 0.0\end{array}$ \\
\hline Umbilical vein & Angiotensin II & $\begin{array}{l}\text { None } \\
o \text {-phenanthroline }\end{array}$ & $\begin{array}{l}4.5 \pm 0.5 \\
0.2 \pm 0.0\end{array}$ \\
\hline Umbilical artery & Angiotensin II & $\begin{array}{l}\text { None } \\
o \text {-phenanthroline }\end{array}$ & $\begin{array}{r}23.0 \pm 0.1 \\
4.4 \pm 0.1\end{array}$ \\
\hline Pulmonary artery & Angiotensin II & $\begin{array}{l}\text { None } \\
o \text {-phenanthroline }\end{array}$ & $\begin{array}{r}18.2 \pm 2.0 \\
0.7 \pm 0.2\end{array}$ \\
\hline
\end{tabular}

The concentration of $\alpha$-L-aspartyl $\beta$-naphthylamide was $0.7 \mathrm{mM}$, the concentration of angiotensin II was $14 \mu \mathrm{M}$, and the concentration of $o$-phenanthroline was $1 \mathrm{mM}$.

to measure each of the enzymes. Since the activity of angiotensin I converting enzyme remained constant for at least five passages, and the cells were compared within the first three passages, it is unlikely that dedifferentiation can account for the differences in enzymatic activities.

Other investigators found that angiotensin I converting enzyme activity is affected by changes in serum

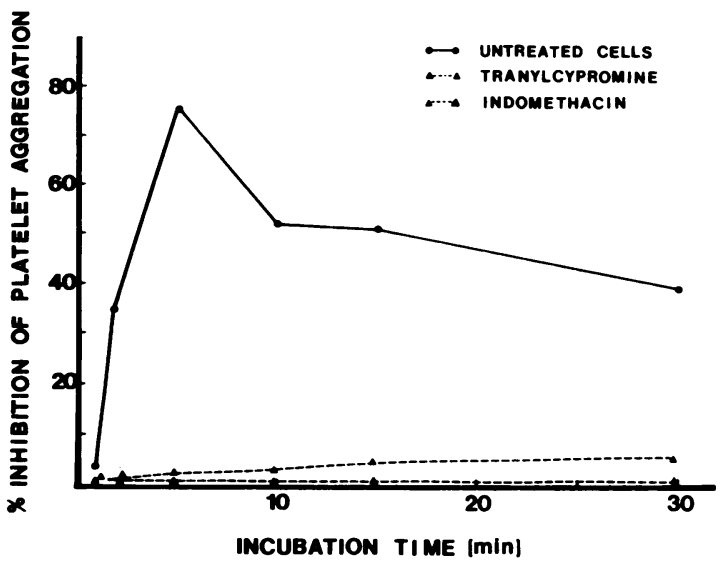

FIGURE 5 Formation of prostacyclin in endothelial cell monolayers. Pulmonary arterial endothelial cells were stimulated by agitation on a rocker platform. Aliquots were drawn immediately after a change of medium and at 2, 5, 10, 15, and $30 \mathrm{~min}$ of agitation. Each aliquot was tested in duplicate for inhibition of platelet aggregation by thrombin $(0.75 \mathrm{u} / \mathrm{ml})$. Closed circles are values for control cells (untreated), open triangles are from cells treated with $100 \mu \mathrm{g} / \mathrm{ml}$ of tranylcypromine, and closed triangles are from cells treated with 1 $\mu \mathrm{g} / \mathrm{ml}$ of indomethacin. concentration or oxygen tension. Hayes et al. (29) noted that cultures of bovine aortic endothelial cells that were maintained in serum-free medium for several days had twice the activity of cells that were grown in media with $20 \%$ fetal calf serum. Leuenberger and associates (41) measured the conversion of angiotensin I to II in the pulmonary vascular beds of dogs and found that hypoxia reduced conversion. Stalcup et al. (42) reported that cultures of human umbilical vein endothelial cells had reduced converting enzyme activity after equilibration with hypoxic gas mixtures. However, since all of the cells in this study were grown under identical conditions, it is unlikely that changes in serum or oxygen can account for differences in enzymatic activities between arterial and venous cells. Probably the differences reflect the specialization of the vessels of origin and indicate that the cultured cells remain highly differentiated.

Pulmonary endothelial cells appear to be no more active than other endothelial cells in metabolizing bradykinin and angiotensin. Although the lung is assumed to be a major site for conversion of angiotensin I (11), only $20-40 \%$ of injected angiotensin I is converted during pulmonary passage in normal human subjects $(9,43)$. The remainder is converted in extrapulmonary beds. Angiotensin II is more readily inactivated in peripheral circulation than in the pulmonary circulation $(9-11)$, thus there appear to be regional differences in the metabolism of vasoactive peptides in vivo. Whereas these differences were not apparent in the cultures of cells from different parts of the body, the greater enzymatic activity associated with cells from arteries may reflect one means of controlling 
TABLE III

Inhibition of Platelet Aggregation by Endothelial Cells

\begin{tabular}{|c|c|c|c|}
\hline Sample origin & Treatment & Volume added & $\begin{array}{l}\text { Inhibition of } \\
\text { aggregation }\end{array}$ \\
\hline & & $\mu l$ & $\%$ \\
\hline \multirow[t]{3}{*}{ Pulmonary artery (M) } & None & 50 & 55 \\
\hline & Indomethacin & 100 & 0 \\
\hline & Tranylcypromine & 100 & 0 \\
\hline \multirow[t]{3}{*}{ Pulmonary artery (S) } & None & 1 & 95 \\
\hline & Indomethacin & 100 & 0 \\
\hline & Tranylcypromine & 100 & 10 \\
\hline Pulmonary artery $(\mathrm{S})$ & $\mathrm{PGH}_{2}$ & 2 & 90 \\
\hline (samples diluted & Indomethacin $+\mathrm{PGH}_{2}$ & 2 & 83 \\
\hline $1: 5)$ & Tranylcypromine $+\mathrm{PGH}_{2}$ & 25 & 5 \\
\hline Pulmonary vein (M) & None & 100 & 28 \\
\hline Pulmonary vein $(\mathrm{S})$ & None & 10 & 40 \\
\hline
\end{tabular}

Samples were media from cell monolayers $(\mathbf{M})$ or from freshly'scraped and suspended cells (S). Drugs were added $5 \mathrm{~min}$ before samples were drawn. $\mathrm{PGH}_{2}$ was added just before cells were scraped, after treatment with drugs.

access of vasoactive peptides into specific vascular beds.

Prostacyclin production by endothelial cells may also depend upon the vessel of origin. Cultured pulmonary endothelial cells, like those from umbilical veins $(30,31)$ can inhibit aggregation of human platelets by a variety of agents. Several observations indicate that this inhibition is due to formation of prostacyclin. First, there is no inhibition by media from cells treated with either indomethacin or tranylcypromine. Tranylcypromine inhibits prostacyclin synthetase, which forms prostacyclin from the endoperoxide, $\mathrm{PGH}_{2}$, and indo-

TABLE IV

Prostacyclin Formation by Endothelial Cells

\begin{tabular}{ccc}
\hline Sample origin & Culture No. & Prostacyclin \\
\hline \multirow{3}{*}{ Pulmonary artery } & & $n$ mol/1/16 cells \\
& 1 & 0.55 \\
Pulmonary vein & 2 & 4.30 \\
& 3 & 2.68 \\
Umbilical cord vein & 1 & 0.10 \\
& 2 & 0.28 \\
& 1 & 0.11 \\
& 2 & 0.08
\end{tabular}

Samples were supernatant media from scraped and suspended cells. Medium was removed from monolayers and replaced with $1 \mathrm{ml}$ of protein-free $\mathrm{M}-199(\mathrm{pH} \mathrm{8.0)}$. The cells were immediately scraped, mixed on a vortex and centrifuged to a pellet. The cell number was determined by assay of DNA in cell pellets. Prostacyclin in the media was estimated by comparison with standard prostacyclin for inhibition of platelet aggregation.
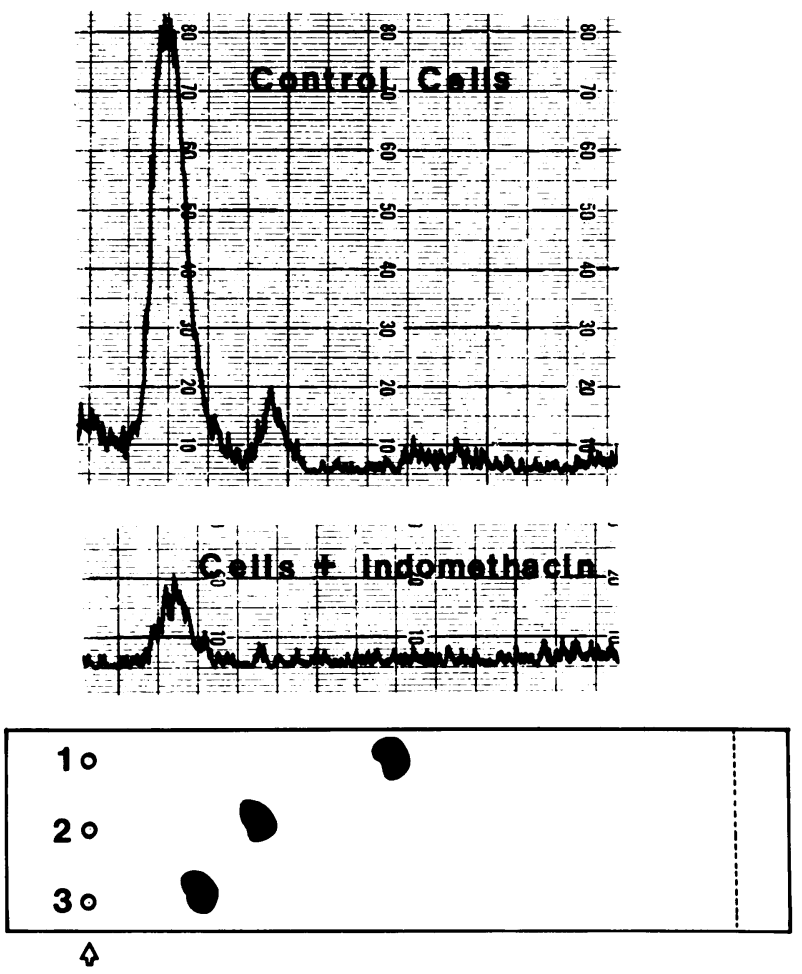

FIGURE 6 Identification of 6-keto $\mathrm{PGF}_{1 \alpha}$ in media from endothelial cells. Cultures of pulmonary arterial cells were stimulated by scraping with a rubber spatula. The transformation of $\left[{ }^{14} \mathrm{C}\right]$ arachidonic acid into prostaglandins was determined by thin-layer chromatography in a solvent system of ethyl acetate:acetic acid:trimethylpentane. Labeled prostaglandins were detected by a radiochromatograph scanner and compared with standards. The arrow indicates the origin on the silica gel plate and the dotted line is the solvent front. Spot $1, \mathrm{PGE}_{2}$; spot $2, \mathrm{PGF}_{2 \alpha}$; and spot 3,6-keto $\mathrm{PGF}_{1 \alpha}$. 
methacin inhibits cyclooxygenase, which forms endoperoxides from arachidonic acid (44). Pulmonary endothelial cells treated with indomethacin could still generate inhibitory activity if they were supplied with $\mathrm{PGH}_{2}$, but cells treated with tranylcypromine could not. Since Marcus and associates (45) showed that cultured endothelial cells can convert $\mathrm{PGH}_{2}$ to prostacyclin via prostacyclin synthetase, it seems likely that the inhibitory material formed by pulmonary endothelial cells is prostacyclin.

The inhibitory material is formed within $2-5 \mathrm{~min}$ after endothelial cell monolayers are stimulated by agitation or scraping. This time-course is similar to that reported for prostacyclin production of fibroblasts and smooth muscle cells (46) and umbilical vein endothelial cells (31-33). The ability to inhibit platelet aggregation is lost, however, if the samples are acidified or heated to $100^{\circ} \mathrm{C}$. Prostacyclin is similarly labile under these conditions (44).

Finally, radiolabeled 6-keto $\mathrm{PGF}_{1 \alpha}$ was identified by thin-layer chromatography in acidified extracts of endothelial cell media. When cell monolayers were incubated with $\left[{ }^{14} \mathrm{C}\right]$ arachidonic acid before stimulation by scraping, the major radioactive product co-chromatographed with 6-keto $\mathrm{PGF}_{1 \alpha}$. Formation of this metabolite was inhibited by indomethacin.

Comparison of media from different endothelial cell cultures on platelet aggregation suggested that pulmonary arterial endothelial cells form more prostacyclin than either pulmonary or umbilical venous cells. Weksler et al. (30) noted that endothelial cells cultured from bovine aorta had approximately 100 times more inhibitory activity than umbilical cord cells on platelet aggregation. From the platelet inhibition bioassay, we estimate that pulmonary arterial cells form between 0.55 and $4.30 \mathrm{nmol}$ of prostacyclin per $10^{6}$ cells, and pulmonary or umbilical venous cells form between 0.1 and $0.28 \mathrm{nmol}$ per $10^{6}$ cells. Czervionke and associates (33) reported that endothelial cells from umbilical veins formed $\sim 0.1 \mathrm{nmol}$ per $10^{6}$ cells when the monolayers were treated with thrombin. Thrombin, like scraping, is a strong stimulus for prostacyclin formation (31). Although Czervionke et al. (33) used a radioimmunoassay for 6-keto $\mathrm{PGF}_{1 \alpha}$, their data for prostacyclin in umbilical vein cells is similar to that obtained with the platelet bioassay.

Others found differences in arterial and venous vessels with respect to their ability to form prostacyclin and 6-keto $\mathrm{PGF}_{1 \alpha}$. Skidgel and Printz (47) used a radiolabeled endoperoxide to measure prostacyclin formation in homogenates of vessels from rats. They found that whereas all of the vessels that they examined could metabolize $\mathrm{PGH}_{2}$ to 6-keto $\mathrm{PGF}_{1 \alpha}$, arteries had consistently more activity than veins.

Several conclusions can be drawn from this study of cultured endothelial cells. First, endothelial cells from all the different human vessels studied contain two markers associated with endothelium in vivo, Factor VIII antigen and angiotensin I converting enzyme. Second, retention of these markers by passaged cells indicates that the cells remain differentiated for at least five passages in culture. Finally, cultured endothelial cells, like endothelium in vivo, can metabolize vasoactive peptides and form prostacyclin. These functions appear to be influenced by the vascular origin of the cultured cells.

\section{ACKNOWLEDGMENTS}

I am grateful to Drs. Ervin G. Erdös and William Campbell of the Departments of Pharmacology and Medicine for their scientific collaboration and advice in the project. I thank Dr. Rolland Reynolds of the Department of Pathology for help in obtaining specimens and for help with photomicrography. I thank Dr. Dan Rightmire of the Department of Obstetrics and Gynecology for donation of surgical specimens. I am most appreciative for the expert techical assistance provided by Mrs. Shashi Rattan, Mrs. Lavinia Noguiera, and Mrs. Manorama John throughout this study.

This work was supported by grants HL 18826 and HL 14187 from the National Institutes of Health.

\section{REFERENCES}

1. Ryan, J. W., U. S. Ryan, D. R. Schultz, C. Whitaker, A. Chung, and F. E. Dorer. 1975. Subcellular localization of pulmonary angiotensin-converting enzyme (kininase II). Biochem. J. 146: 497-499.

2. Caldwell, P. R. B., B. C. Seegal, K. C. Hsu, M. Das, and R. L. Soffer. 1976. Angiotensin-converting enzyme: vascular endothelial localization. Science (Wash. D. C.). 191: 1050-1051.

3. Yang, H. Y. T., E. G. Erdös, and Y. Levin. 1971. Characterization of a dipeptide hydrolase (kininase II: angiotensin I converting enzyme). J. Pharmacol. Exp. Ther. 177: 291-300.

4. Igic, R., E. G. Erdös, H. S. J. Yeh, K. Sorrels, and T. Nakajima. 1972. Angiotensin I converting enzyme of the lung. Circ. Res. 31(Suppl. II): 51-61.

5. Biron, P., and C. G. Huggins. 1968. Pulmonary activation of synthetic angiotensin I. Life Sci. 7: 965-970.

6. Aiken, J. W., and J. R. Vane. 1972. Inhibition of converting enzyme of the renin-angiotensin system in kidneys and hindlegs of dogs. Circ. Res. 30: 263-273.

7. Collier, J. G., and B. F. Robinson. 1974. Comparison of effects of locally infused angiotensin I and II on hand veins and forearm arteries in man: evidence for converting enzyme activity in limb vessels. Clin. Sci. Mol. Med. 47: 189-192.

8. Ryan, U. S., J. W. Ryan, C. Whitaker, and A. Chiu. 1976. Localization of angiotensin converting enzyme (kininase II). II. Immunocytochemistry and immunofluorescence. Tissue Cell. 8: 125-145.

9. Biron, P., L. Campeau, and P. David. 1969. Fate of angiotensin I and II in the human pulmonary circulation. Am. J. Cardiol. 24: 544-547.

10. Bakhle, Y. S., A. M. Reynard, and J. R. Vane. 1969. Metabolism of the angiotensins in isolated perfused tissues. Nature (Lond.). 222: 956-959.

11. Vane, J. R. 1969. The release and fate of vaso-active hormones in the circulation. Br. J. Pharmacol. 35: 209-242.

12. Jaffe, E. A., R. L. Nachman, C. G. Becker, and C. R. Minick. 1973. Culture of human endothelial cells derived from 
umbilical veins. Identification by morphologic and immunologic criteria. J. Clin. Invest. 52: 2745-2756.

13. Lewis, L. J., J. C. Hoak, R. D. Maca, and G. L. Fry. 1973. Replication of human endothelial cells in culture. Science (Wash. D. C.). 181: 453-454.

14. Gimbrone, M. A., R. S. Cotran, and J. Folkman. 1974. Human vascular endothelial cells in culture. Growth and DNA synthesis. J. Cell Bio. 60: 673-684.

15. Johnson, A. R., and E. G. Erdös. 1977. Metabolism of vasoactive peptides by human endothelial cells in culture. Angiotensin I converting enzyme (kininase .II) and angiotensinase. J. Clin. Invest. 59: 684-695.

16. Johnson, A. R., and E. G. Erdös. 1979. Angiotensin I converting enzyme (kininase II) in human endothelial cells in culture. In Kinin 78 Tokyo. International Symposium on Kinins. T. Suzuki and H. Moriya, editors. Plenum Publishing Corp., New York.

17. Loskutoff, D. J., and T. S. Edgington. 1977. Synthesis of a fibrinolytic activator and inhibitor by endothelial cells. Proc. Natl. Acad. Sci. U. S. A. 74: 3903-3907.

18. Pearson, J. D., H. J. Olverman, and J. L. Gordon. 1977. Transport of 5-hydroxytryptamine by endothelial cells. Biochem. Soc. Trans. 5: 1181-1183.

19. Booyse, F. M., A. J. Quarfoot, S. Bell, D. N. Fass, J. C. Lewis, K. G. Mann, and E. J. W. Bowie. 1977. Cultured aortic endothelial cells from pigs with von Willebrand disease. In vitro model for studying the molecular defect(s) of the disease. Proc. Natl. Acad. Sci. U. S. A. 74: 5702-5706.

20. Dieterle, Y., C. Ody, A. Ehrensberger, H. Stalder, and A. Junod. 1978. Metabolism and uptake of adenosine triphosphate and adenosine by porcine aortic and pulmonary endothelial cells and fibroblasts in culture. Circ. Res. 42: 869-876.

21. Booyse, F. M., B. J. Sedlak, and M. E. Rafelson. 1975. Culture of arterial endothelial cells. Characterization and growth of bovine aortic cells. Thromb. Diath. Haemorrh. 34: 825-839.

22. Shepro, D., J. C. Batbouta, L. S. Robblee, M. P. Carson, and F. A. Belamarich. 1975. Serotonin transport by cultured bovine aortic endothelium. Circ. Res. 36: 799-806.

23. Gospodarowicz, D., J. Moran, D. Braun, and C. Birdwell. 1976. Clonal growth of bovine vascular endothelial cells: fibroblast growth factor as a survival agent. Proc. Natl. Acad. Sci. U. S. A. 73: 4120-4124.

24. Macarak, E. J., B. V. Howard, and N. A. Kefalides. 1977. Properties of calf endothelial cells in culture. Lab. Invest. 36: $62-67$.

25. Haudenschild, C. C., R. S. Cotran, M. A. Gimbrone, and J. Folkman. 1975. Fine structure of vascular endothelium in culture. J. Ultrastruct. Res. 50: 22-32.

26. Gimbrone, M. A. 1976. Culture of vascular endothelium. In Progress in Hemostasis and Thrombosis Vol. III. T.H. Spaet, editor. Grune \& Stratton, Inc., New York. 1-28.

27. Gospodarowicz, D., G. Greenberg, H. Bialecki, and B. R. Zetter. 1978. Factors involved in the modulation of cell proliferation in vivo and in vitro: the role of fibroblast and epidermal growth factors in the proliferative response of mammalian cells. In Vitro (Rockville). 14: 85-118.

28. Ryan, J. W., and U. S. Ryan. 1977. Pulmonary endothelial cells. Fed. Proc. 36: 2683-2691.

29. Hayes, L. W., C. A. Goguen, S.-F. Ching, and L. L. Slakey. 1978. Angiotensin-converting enzyme: accumulation in medium from cultured endothelial cells. Biochem. Biophys. Res. Commun. 82: 1147-1153.

30. Weksler, B. B., A. J. Marcus, and E. A. Jaffe. 1977.
Synthesis of prostaglandin $I_{2}$ (prostacyclin) by cultured human and bovine endothelial cells. Proc. Natl. Acad. Sci. U. S. A. 74: 3922-3926.

31. Weksler, B. B., C. W. Ley, and E. A. Jaffe. 1978. Stimulation of endothelial cell prostacyclin production by thrombin, trypsin, and the ionophore A 23187. J. Clin. Invest. 62: 923-930.

32. Baenziger, N. L., P. R. Becherer, and P. W. Majerus. 1979. Characterization of prostacyclin synthesis in cultured human arterial smooth muscle cells, venous endothelial cells and skin fibroblasts. Cell. 16: 967-974.

33. Czervionke, R. L., J. B. Smith, J. C. Hoak, G. L. Fry, and D. L. Haycraft. 1979. Use of a radioimmunoassay to study thrombin-induced release of $\mathrm{PGI}_{2}$ from cultured endothelium. Thromb. Res. 14: 781-786.

34. Johnson, A. R., and E. G. Erdös. 1978. Enzyme activities in human pulmonary endothelial cells in culture. Circulation. 58(Suppl. II): 108.

35. Burton, K. 1968. Determination of DNA concentration with diphenylamine. Methods Enzymol. 12(Part B): 163- 166.

36. Ondetti, M. A., N. J. Williams, E. F. Sabo, J. Pluscec, E. R. Weaver, and O. Kocy. 1971. Angiotensin-converting enzyme inhibitors from the venom of Bothrops jararaca. Isolation, elucidation of structure, and synthesis. Biochemistry. 10: 4033-4039.

37. Ryan, J. W., A. Chung, C. Ammons, and M. L. Carlton. 1977. A simple radioassay for angiotensin-converting enzyme. Biochem. J. 167: 501-504.

38. Nagatsu, I., L. Gillespie, J. M. George, J. E. Folk, and G. G. Glenner. 1965. Serum aminopeptidases, "angiotensinase," and hypertension-II. Amino acid $\beta$-naphthylamide hydrolysis by normal and hypertensive serum. Biochem. Pharmacol. 14: 853-861.

39. Hoyer, L. W., R. P. de los Santos, and J. R. Hoyer. 1973. Antihemophilic factor antigen. Localization in endothelial cells by immunofluorescent microscopy. J. Clin. Invest. 52: 2737-2744.

40. Jaffe, E. A., L. W. Hoyer, and R. L. Nachman. 1973. Synthesis of antihemophilic factor antigen by cultured endothelial cells. J. Clin. Invest. 52: 2757-2764.

41. Leuenberger, P. J., S. A. Stalcup, R. B. Mellins, L. M. Greenbaum, and G. M. Turino. 1978. Decrease in angiotensin I conversion by acute hypoxia in dogs. Proc. Soc. Exp. Biol. Med. 158: 586-589.

42. Stalcup, S. A., J. S. Lipset, J. M. Woan, P. J. Leuenberger, and R. B. Mellins. 1979. Inhibition of angiotensin converting enzyme activity in cultured endothelial cells by hypoxia. J. Clin. Invest. 63: 966-976.

43. Biron, P., and L. Campeau. 1971. Pulmonary and extrapulmonary fate of angiotensin I. Rev. Can. Biol. 30: 27-34.

44. Marcus, A. J. 1978. The role of lipids in platelet function: with particular reference to the archidonic acid pathway. J. Lipid Res. 19: 793-826.

45. Marcus, A. J., B. B. Weksler, and E. A. Jaffe. 1978 Enzymatic conversion of prostaglandin endoperoxide $\mathrm{H}_{2}$ and arachidonic acid to prostacyclin by cultured human endothelial cells. J. Biol. Chem. 253: 7138-7141.

46. Baenziger, N. L., M. J. Dillender, and P. W. Majerus. 1977. Cultured human skin fibroblasts and arterial cells produce a labile platelet-inhibitory prostaglandin. Biochem. Biophys. Res. Commun. 78: 294-301.

47. Skidgel, R. A., and M. P. Printz. 1978. $\mathrm{PGI}_{2}$ production by rat blood vessels: diminished prostacyclin formation in veins compared to arteries. Prostaglandins. 16: 1-16. 